\title{
PSYCHOLOGICAL ADJUSTMENT TO INJURY AND ACUTE TRAUMA ${ }^{\dagger}$
}

\author{
HEIN HELGo SCHOMER B.A. (Hons) M.A. (Psychology)*
}

\begin{abstract}
SUMMARY
Man lives in an ever-changing environment. To maintain a relative state of psychological homeostasis essential for optimal functioning man has to learn how to adapt effectively to the manifold demands made on him by the complex social system in which he lives in. For any adaptive behaviour to be maximally successful a person has to possess clear insights into his capacities, values and self-concept. A simple personality model is outlined to elucidate psychological adaptive behaviour processes and to illustrate what impact injury and acute trauma can have on a person's functioning. In order to make treatment more incisive physiotherapists have to be aware of the psychological adjustments required to cope with injury and acute trauma. Implications are discussed.
\end{abstract}

\section{OPSOMMING}

Die mens leef in 'n altyd veranderende omgewing. Om 'n toestand van relatiewe sielkundige homeostase, essensieel vir optimale funksionering, te handhaaf, moet die mens leer om effektief aan te pas by die menigvuldige eise wat van hom geverg word in die ingewikkelde sosiale stelsel waarin hy leef. Vir enige aanpassingsgedrag om maksimaal suksesvol te wees, moet 'n persoon duidelike insig in sy bekwaamhede, waardes en selfbegrip hê. 'n Eenvoudige persoonlikheidsmodel word geskets om sielkundige aanpassingsgedragsprossesse te verduidelik en om te illustreer watter aanslag besering en akute trauma op 'n persoon se funksionering kan, hè. Om behandeling meer kragtig te maak, moet fisioterapeute meer bewus wees van die sielkundige aanpassings wat nodig is om opgewasse te wees teen besering en akute trauma. Implikasies word bespreeek.
The world around us changes all the time. This "outer" world consists of both natural factors, like temperature and sunlight, and social factors like work demand and peer group composition. Humans have had to learn to adapt to the changing demands of such a world. Most of us have learnt to adapt quite effectively. We are the fortunate ones with the capacity to make adjustments to keep our body and mind working in a balanced way. We maintain a relative physiological and psychological state of homeostasis. We have learnt to cope; we deal with events and their effects. Put in another way, we take actions to promote our effectiveness as it is associated with psychological achievements - we are nentally healthy.

The adjustments demanded from us to cope with life's activities sometimes mean that we have to behave in a way to change the environment, the outer world, to a more compatible one with our goals and aspirations. Most of the time though, adjustments mean change in the inner world in us. The environment maintains its status quo and we adjust to be able to deal with the status quo more effectively. We adapt.

Adaptation may take several forms. Some are more psychologically economical than others. If, for instance, you believe yourself to be at the mercy of taxing events or aggravating demands, you will most probably cope in a reactive way; fight or flight. This coping behaviour is of ten accompanied by frustrations, self-blame, chronic fatigue, tension or acts of self-indulgence, like overeating, excessive smoking or drug and alcohol abuse.

$\dagger$ Talk delivered at Orthopaedics Trauma Symposium, Physiotherapy Silver Jubilee Week, UCT, 8 April 1983. *Lecturer in the Dept, of Psychology, UCT and at Medical School in the B.Sc. (Med) (Hons) Sport Science course. Received 20 May 1983.
You are far better off when you perceive yourself to be in control of your own behaviour and patterns of interaction. Active ways of coping denote that you are deciding what needs to be changed and how you will implement that change. Problem solving, exercise, relaxation therapy, healthy eating habits and work are all active ways of coping.

Coping takes place unconsciously and consciously. We do not have to tell ourselves when it gets to $28^{\circ}$ outside to sweat. Our autonomic nervous system takes care of the appropriate response here. Neither do we really consciously register varied adaptations that our mind and body go through to deal with the stresses and strains of daily living. $1 \mathrm{t}$ is when our mind must confront complicated critical problems with no simple single obvious solution that conscious coping has to take place.

For this adaptive behaviour to be optimally successful, we have to possess personal insights in to our capacities, values and self-concept. The more accurate our insights, the more precise our assessment of our capacities, the better our selfconcept. We are more likely to make effective adjustments to life's situations the more defined our self-concept is. A clear self-concept is crucial in determining our immediate behaviour and for further personality development. A clear self-concept includes a definite perception of one's basic roles, dispositions and body image. A sense of self emerges gradually throughout childhood. It forms the framework into which all past, present and future experiences are integrated. It makes up a major part of the individual's personality.

Personality may be viewed as the sum total of a person's characteristics that indicates his uniqueness and (at the same time) his amalgamation as a social being. A person's distinguishing characteristics are inextricably tied up with the society he lives in. This relationship is a direct consequence of the fact that an individual's personality 
develops as a function of psycho-social adjustments. In this process the life-long necessity to balance individual needs and social requirements is cardinal.

It will be advantageous at this stage to outline a modified form of Hollander's (I967) personality model. Personality can be seen to manifest itself at four distinct levels:

I. The core-concept (a primal perception of the person's life force)

2. The psychological core constructs (values, attitudes, beliefs, interests and motives)

3. The typical responses (characteristic manner in responding to frustration, humour and anxieties) and

4. The role-related behaviours (behaviour in accordance to perceived social position, status and norms).

Schematically this modified model can be represented as four concentric circles inside a social environment (Figure l). The four levels are closely interrelated. Level one and two form what has previously been referred to as self-concept. These levels also contain less conscious effects of past experiences. There is an internal and external dimension to this personality model. Whereas the core-concept is the extreme internal, the role related behaviours are at the extreme external end of the continuum. Internal levels are relatively stable and coherent. External levels are subject to change due to their exposure to the social environment around us.

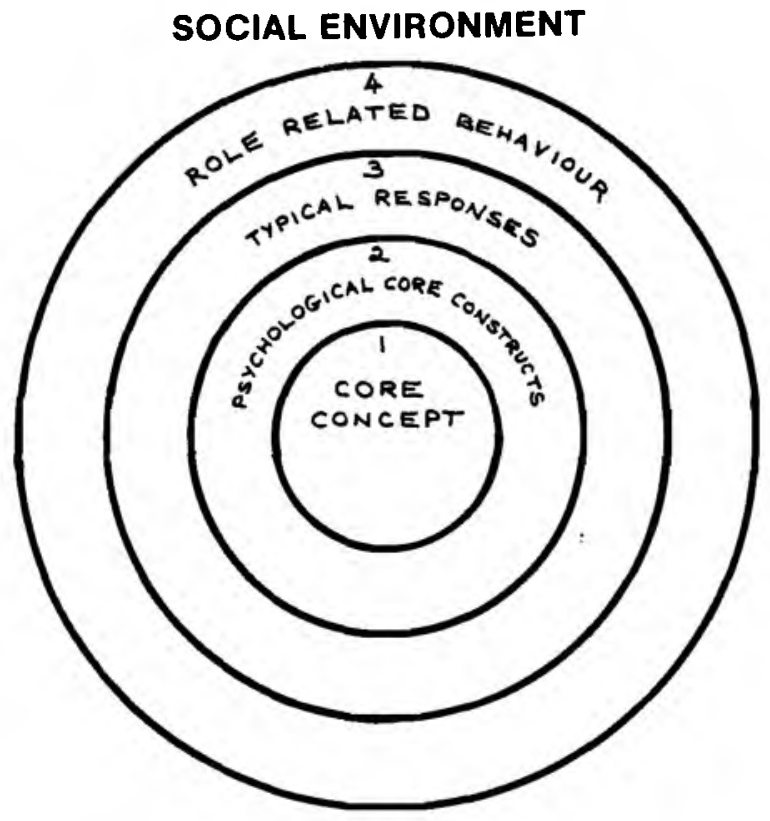

Fig. I.

\section{SCHEMATIC REPRESENTATION OF PERSONALITY MODEL}

This implies that there are consistent as well as dynamic components to a personality. The dynamic component allows for changes due to learning (adaptive behaviour) and the consistent components provide the needed structure (reference point for homeostatic process) for an individual to function in an ever changing world. Influences from the environment act first of all on the external levels four and three, and depending on how much adjustment is required from the individual to deal effectively with the situation, may penetrate to the internal levels. The permeability of the levels with respect to the influences of the environment decreases rapidly as we approach the core-concept.

When we come to encounter someone new, we are usually aware of the specific social environment in which the meeting takes place. Specific social environments make us behave, dress and perceive events and people around us in specific lights. We don't behave, dress or look at people at the State Opera as we do at home. Within reasonable limits we tend to conform to the acceptable social norm. We yield to the perceived situational demand. We register people around us according to the role they seem to play in the given situation. Even when encountering a person in only one given situation, fulfilling a given role, we start generalising excessively about that person's typical personality from just that limited basis. We might have the opportunity to get to know the person better, to talk to him or to see him in more than one situation. We might discover that our initial inductions/deductions were only partly right. We might have been wrong. But only after extensive exposure and interaction with a person do we come to know his psychological core constructs and finally his core-concept. As the impact of influences from the social environment decreases, as we go from the outer levels to the inner levels of the person, so does the ability to recognise the inner levels for another person. Back to the processes within the person.

Events that demand adjustment are interpreted as stress. Usually a person can cope with these demands by making some adjustments at the external levels, namely the rolerelated behaviours or the typical responses. Our system usually survives the occasional attack on our internal levels, viz. our core constructs and our core-concept. Here we are talking about the mentally healthy person. But stress can accumulate and persist. Highly stressful influences may penetrate right down into the centre, to the core-concept. Accumulation and persistence of highly stressful influences may cause the system to go off balance, i.e. to lose its homeostatic state. When you feel more stress than you can cope with, your mental health is in danger. The system will dysfunction.

Physiological injury and acute trauma are stressful events. Nursing a bruised knee after a social soccer game at the weekend may be ignored. It is irritating, but not interpreted as stress. Going to work with your leg in plaster may be seen as light stress by a student, not so light by a manager who has to fly to Europe to clinch another million-dollar deal. Playing the role of injured is usually short-lived and peripheral. The individual does not have to make adjustments to his typical responses or core. One usually has the chance to play the role of the injured several times during childhood. It is not new and one has some idea in advance about its requirements. Yet there will be the occasional reactive response. On the other hand, losing a leg in a car after too much merry-making at the office party is severe stress: the consequences chronic and the implications never thought of by the majority of people. Such an event has a pervasive effect upon the whole personality of the individual because of the totality and persistence of the psychological as well as physiological adjustments the person has to live through. Such a severely stressful event penetrates right down to the core-concept. The person has to adjust his outlook on life and living, on his role as a husband/wife, as a provider/supporter. His feelings and beliefs will undergo radical changes. Can the person maintain the role he once played - father, mother, postman, manager or nurse? The person who has to live through a trauma similar to the one outlined above is continually reminded of his new position by other individuals' actions towards him, which in turn affect the core of his personality, 
most notably his self-image, but also his attitudes, values and beliefs.

Generally speaking, the more severe the injury and the more lasting the consequences from acute trauma, the more stress is felt - and the more psychological adjustments have to be made - and the more likely that the person dysfunctions. Signs of dysfunction are quite distinct. At the first level coping abilities are clearly reduced. The person talks and laughs too much, loses his temper too often, feels restless and worries. Loss of appetite and sleeplessness occur. With quite a bit of drinking, smoking and sleeping pills, life can go on. The second level is marked by a strong sense of anxiety, obsessive-compulsive behaviour, phobias and depression. The person is neurotic. Perceptions of the realworld remain intact, though, for most of the time. Again, life can go on. On the third level of dysfunction a person starts to act aggressions out openly. The person is no longer fully in touch with reality. An attempt is made to seem normal. This is dropped at the fourth level. Actions are no longer based on real-world demands and needs, behaviour becomes unpredictable, aggressive and regressive impulses can no longer be controlled. This is psychosis - insanity. The individual withdraws from the family, friends and work into a fantasy world. What is left at the last level, level five, is a marked loss in the will to live and a resolve to end life is made. Suicide.

What does all this mean to the Physiotherapist? It is most important that the patient's mental health is monitored during treatment. The more severe the injury or trauma the more you will have to be on the look-out; deteriorating mental health will prolong or even prevent physiological recovery. The physiotherapist has to take the patient's fears and anxieties into account. The physiotherapist will benefit and derive more satisfaction from his/her work the more he/she is aware of the psychological adjustment the patient has to process. Be sensitive and assertive at the same time. Severe signs of dysfunction should be a warning signal. Severe physical impairment and subsequent adjustment are crisis periods - the physiotherapist can provide support and empathy without attempting to reconstruct a patient's personality. Effective problem solving in the more severe cases means seeking out professional help.

A productive life is determined by the quality of our mental health. Mental health is a relative state of functioning. It is the quality of a person's usual or integrated intrapersonal and interpersonal relationships. Deteriorating mental health means poor relationships with friends, family and colleagues, as well as the self. These relationships determine to what extent life is worthwhile, pleasant, happy and productive. You have a role to play. You can enhance your patient's relationships.

\section{References}

Hollander, EP. Principles and methods of social psychology New York: Oxford University Press, (1967).

Hollander, EP. \& Hunt, R. Current perspectives in social psychology. New York: Oxford University Press, (1967).

\section{EXTENSION OF THE PROFESSION}

The post of Control Physiotherapist has been created by the Transvaal Department of Hospital Services at Pretoria. This is the first purely administrative post in the hospital services in South Africa. It is hoped that this will be the start of greater control of the profession by physiotherapists themselves.

Miss Elsa Smit has been appointed to the position. We wish her luck with her new post and hope that this is the beginning of greater things and that posts will be created by the other provinces so that the profession can advance and be recognized in its own right.

\section{PORPHYRIA - A DANGEROUS GENETIC PUZZLE}

A pamphlet has recently been released on this subject by the Public Relations Department, S.A. Medical Research Council, P.O. Box 70, Tygerberg 7505 .

This is a fairly widespread genetic disease and the authorities are anxious to trace as many sufferers of this condition as possible.

Anyone who suspects he may have porphyria should contact their nearest regional office of the Department of Health and Welfare for tests.

Pamphlets are also available from the MRC Porphyria Research Unit at the University of Cape Town. 